\title{
Salinicoccus salsiraiae sp. nov.: a new moderately halophilic gram-positive bacterium isolated from salted skate
}

\begin{abstract}
Two moderately halophilic low G + C Grampositive bacteria were isolated from a sample of salted skate (Class Chondrychthyes, Genus Raja). Phylogenetic analysis of the $16 \mathrm{~S}$ rRNA gene sequence of strains $\mathrm{RH} 1^{\mathrm{T}}$ and RH4 showed that these organisms represented a novel species of the genus Salinicoccus. The new isolates formed pink-red colonies and flocculated in liquid media, with optimum growth in media containing $4 \%$ $\mathrm{NaCl}$ and $\mathrm{pH}$ of about 8.0. These organisms are aerobic but reduce nitrate to nitrite under anaerobic conditions. Acid is produced from several carbohydrates. Oxidase and catalase were detected. Menaquinone 6 was the major respiratory quinone. The major fatty acids of strains $\mathrm{RH} 1^{\mathrm{T}}$ and $\mathrm{RH} 4$ were 15:0 anteiso and 15:0 iso. The $\mathrm{G}+\mathrm{C}$ contents of DNA were 46.2 and $46.0 \mathrm{~mol} \%$, respectively. The peptidoglycan was of A3alpha L-LysGly $_{5-6}$ type. On the basis of the phylogenetic analyses, physiological and biochemical characteristics, we suggest that strain $\mathrm{RH}^{\mathrm{T}}{ }^{\mathrm{T}}$ (=LMG $22840=\mathrm{CIP} 108576$ ) represents a new species of the genus Salinicoccus, for which we propose the name Salinicoccus salsiraiae.
\end{abstract}

Keywords Salinicoccus salsiraiae sp. nov. 'Halophilic · Salted skate

Communicated by G. Antranikian

L. França $\cdot$ M. S. da Costa $(\bowtie)$

Departamento de Bioquímica,

Centro de Neurociências e Biologia Celular,

Universidade de Coimbra, 3001-401 Coimbra, Portugal

e-mail: milton@ci.uc.pt

Tel.: + 351-239-824024

Fax: + 351-239-826798

F. A. Rainey

Department of Biological Sciences,

Louisiana State University, Baton Rouge, LA, 70803 USA

M. F. Nobre

Departamento de Zoologia, Universidade de Coimbra, 3004-517 Coimbra, Portugal

\section{Introduction}

Two moderately halophilic species of the genus Salinicoccus, named Salinicoccus roseus (Ventosa et al. 1990) and Salinicoccus hispanicus (Marquez et al. 1990; Ventosa et al. 1992) were isolated from solar salterns in Spain. These strains have optimum growth around neutral $\mathrm{pH}$ and grow optimally in the presence of about $8 \% \mathrm{NaCl}$. Another organism, named Salinicoccus alkaliphilus, represents an additional lineage within the genus Salinicoccus was isolated from a soda lake in Inner Mongolia, China (Zhang et al. 2002). This organism is also moderately halophilic but has an optimum $\mathrm{pH}$ for growth around 9.5.

We recently isolated two moderately halophilic, aerobic Gram-positive cocci, designated $\mathrm{RH} 1^{\mathrm{T}}$ and $\mathrm{RH} 4$ from salted skate (Class Chondrychthyes, Genus Raja). Phenotypic and chemotaxonomic characterization and phylogenetic analysis based on 16S rRNA gene sequences showed that these isolates were related to organisms of the genus Salinicoccus but represent a new species for which we propose the name Salinicoccus salsiraiae.

\section{Materials and methods}

Isolation and bacterial strains

The novel strains, designated $\mathrm{RH} 1^{\mathrm{T}}(\mathrm{T}=$ type strain $)$ and $\mathrm{RH} 4$, were isolated from a sample of salted skate of the genus Raja. Salted fish samples (16-18 g) were homogenized in sterile blenders with sterile $5 \% \mathrm{NaCl}$ solution. One drop of the homogenate was spread on Degryse 162 (Degryse et al. 1978) agar plates containing $5 \% \mathrm{NaCl}$. These preparations were incubated at $37^{\circ} \mathrm{C}$ for up to 5 days. Cultures were purified by sub-culturing and pure cultures were maintained at $-80^{\circ} \mathrm{C}$ in Degryse 162 medium with $5 \% \mathrm{NaCl}$ and $15 \%$ glycerol. The type strains of S. roseus $\left(9^{\mathrm{T}}=\operatorname{DSM} 5351^{\mathrm{T}}\right)$ and $S$. hispanicus 
$\left(\mathrm{J}-82^{\mathrm{T}}=\right.$ DSM $\left.5352^{\mathrm{T}}\right)$ were used for comparative purposes.

\section{Phenotypic characterization}

Unless otherwise stated, all morphological examinations, biochemical and tolerance tests were performed as described previously (Santos et al. 1989; Nunes et al. 1992), in 10\% MH medium (Ventosa et al. 1982) (http:// www.dsmz.de/media/med593.htm) as follows (\%, w/v): $\mathrm{MgCl}_{2}, 0.7 ; \mathrm{MgSO}_{4}, 0.96 ; \mathrm{CaCl}_{2}, 0.036 ; \mathrm{KCl}, 0.2$; $\mathrm{NaHCO}_{3}, 0.006 ; \mathrm{NaBr}, 0.0026$; proteose-peptone no. 3, 0.5 ; yeast extract, 1.0 and glucose, 0.1 . The levels of $\mathrm{NaCl}$ in the medium varied from 0 to $25 \%$. Routine analysis of strains $\mathrm{RH}^{\mathrm{T}}$ and $\mathrm{RH} 4$ was carried out in $10 \% \mathrm{MH}$ medium containing $4 \% \mathrm{NaCl}$.

A sonication bath (Bransonic 12, $50 \mathrm{kHz}$ ) was used to disperse clumps of strains $\mathrm{RH}^{\mathrm{T}}$ and $\mathrm{RH} 4$ grown in liquid medium. Turbidity was monitored at $610 \mathrm{~nm}$. The $\mathrm{NaCl}$ range for growth of the organisms was examined in liquid medium containing $0-26 \%(\mathrm{w} / \mathrm{v}) \mathrm{NaCl}$, in a reciprocal water-bath shaker. The growth temperature range was determined in the same medium between 15 and $50^{\circ} \mathrm{C}$. The $\mathrm{pH}$ range for growth was determined at $37^{\circ} \mathrm{C}$ in the same medium with $100 \mathrm{mM}$ MES, HEPES, TAPS and CAPSO.

Enzymatic tests were performed using API ZYM test strips (BioMérieux) as recommended by the manufacturer, but with $4 \% \mathrm{NaCl}(\mathrm{w} / \mathrm{v})$. Results were recorded after $4 \mathrm{~h}$ incubation at $37^{\circ} \mathrm{C}$. Single carbon source assimilation tests were performed in a basal liquid medium described by Ventosa et al. (1982) to which filter-sterilized yeast extract $(0.1 \mathrm{~g} / \mathrm{l})$, ammonium chloride $(0.5 \mathrm{~g} / 1)$ and the carbon sources $(2.0 \mathrm{~g} / 1)$ were added. Growth of the strains was examined by measuring the turbidity of cultures incubated at $37^{\circ} \mathrm{C}$ as described previously (Moreira et al. 2000). Degryse 162 medium basal salts and ABM2 basal medium (Tiago et al. 2004) were also used to assess the assimilation of single carbon sources. API $50 \mathrm{CH}$ test strips (Analytab Products Inc., BioMérieux) were also used to examine the assimilation of carbohydrates and to examine the production of acid using a defined medium (Ventosa et al. 1982) containing the following components per litre: $\mathrm{NaCl}, 40.0 \mathrm{~g}$ (for strains $\mathrm{RH}^{\mathrm{T}}$ and RH4) or $80.0 \mathrm{~g}$ (for S. roseus and $S$. hispanicus); $\mathrm{MgSO}_{4} \cdot 7 \mathrm{H}_{2} \mathrm{O}, 2.0 \mathrm{~g} ; \mathrm{CaCl}_{2} \cdot 2 \mathrm{H}_{2} \mathrm{O}, 0.5 \mathrm{~g}$; $\mathrm{FeCl}_{3} \cdot 6 \mathrm{H}_{2} \mathrm{O}$, traces; $\mathrm{KH}_{2} \mathrm{PO}_{4}, 0.5 \mathrm{~g}$; proteose-peptone no. 3, $1.0 \mathrm{~g}$; yeast extract, $0.1 \mathrm{~g}$; agar, $3.0 \mathrm{~g}$; phenol red, $0.01 \mathrm{~g}$.

Peptidoglycan, lipoquinone and fatty acid composition

Purified cell wall preparations were obtained and the identification of the peptidoglycan type was performed using previously described methods (Schleifer and Kandler 1972; Schleifer 1985). Lipoquinones were extracted from freeze-dried cells and purified by TLC as described previously (Tindall 1989; Moreira et al. 2000; Freitas et al. 2003). Cultures for fatty acid analysis were grown on plates of modified $10 \% \mathrm{MH}$ medium containing $8 \% \mathrm{NaCl}$ in sealed plastic bags submerged in a water-bath at $37^{\circ} \mathrm{C}$ for $24 \mathrm{~h}$. Fatty acid methyl esters (FAMEs) were obtained from fresh wet biomass; the identification and quantification of the FAMEs and the numerical analysis of the fatty acid profiles were performed by using the standard MIS library Generation Software (Microbial ID Inc., Netwark. Del).

Determination of $\mathrm{G}+\mathrm{C}$ content of DNA, 16 rRNA gene sequence and phylogenetic analysis

The DNA for the determination of the $\mathrm{G}+\mathrm{C}$ content of the DNA was isolated as described by Nielsen et al. (1995). The G + C content of DNA was determined by high-performance liquid chromatography as described by Mesbah et al. (1989). The extraction of genomic DNA for 16S rRNA gene sequence determination, PCR amplification of the 16S rRNA gene and sequencing of the purified PCR products were carried out as described previously (Rainey et al. 1996). Purified reactions were electrophoresed using a model 310 Genetic Analyzer (Applied Biosystems). The 16S rRNA gene sequences were aligned against representative reference sequences of members of the low $\mathrm{G}+\mathrm{C}$ Gram-positive phylum using the ae 2 editor (Maidak et al. 1999). The method of Jukes and Cantor (1969) was used to calculate evolutionary distances. Phylogenetic dendrograms and bootstrap analyses were generated using various algorithms contained in the PHYLIP package (Felsenstein 1993). The 16S rRNA gene sequence of strain $\mathrm{RH}^{\mathrm{T}}{ }^{\mathrm{T}}$ is available in the GenBank database under the accession number DQ333949.

\section{Results}

Morphological and biochemical characteristics

Isolates $\mathrm{RH}^{\mathrm{T}}$ and $\mathrm{RH} 4$ formed round pink-red pigmented colonies and coccoid-shaped Gram-positive cells with $1.0-2.5 \mu \mathrm{m}$ in diameter occurring singly, in pairs, tetrads or clumps and were not motile. Endospores were not formed. Both strains flocculated in the liquid growth media used. The optimum concentration of $\mathrm{NaCl}$ for growth was about $4 \%$, growth was observed in medium without additional $\mathrm{NaCl}$ and with $22 \% \mathrm{NaCl}$ (Table 1). The type strains of $S$. roseus and $S$. hispanicus had optimum $\mathrm{NaCl}$ concentrations for growth around 8$10 \%$ and growth was not observed above $25 \% \mathrm{NaCl}$. The growth temperature range of strains $\mathrm{RH}^{\mathrm{T}}$ and RH4 was between 20 and $45^{\circ} \mathrm{C}$ with an optimum growth temperature of about $37^{\circ} \mathrm{C}$. The $\mathrm{pH}$ range for growth was between 6.5 and 9.5, with an optimum around 8.0. Strains $\mathrm{RH}^{\mathrm{T}}$ and $\mathrm{RH} 4$ were strictly aerobic, but reduced nitrate to nitrite under anaerobic conditions. 
Table 1 Characteristics that distinguish strains $\mathrm{RH}^{\mathrm{T}}$ and $\mathrm{RH} 4$ from the type strains of Salinicoccus roseus, Salinicoccus hispanicus and Salinicoccus alkaliphilus

\begin{tabular}{|c|c|c|c|c|}
\hline Characteristics & $\mathrm{RH} 1^{\mathrm{T}} / \mathrm{RH} 4^{\mathrm{a}}$ & S. roseus ${ }^{\mathrm{Ta}}$ & S. hispanicus ${ }^{\mathrm{Ta}}$ & S. alkaliphilus ${ }^{\mathrm{Tb}}$ \\
\hline \multicolumn{5}{|l|}{ Temperature $\left({ }^{\circ} \mathrm{C}\right)$ for growth } \\
\hline Range & $20-45$ & $20-45$ & $20-45$ & $10-49$ \\
\hline Optimum & 37 & 37 & 37 & 32 \\
\hline \multicolumn{5}{|l|}{$\mathrm{pH}$ for growth } \\
\hline Range & $6.5-9.5$ & $6.5-9.5$ & $6.5-9.5$ & $6.5-11.5$ \\
\hline Optimum & 8.0 & 8.0 & 8.0 & 9.5 \\
\hline \multicolumn{5}{|l|}{$\mathrm{NaCl}(\%, \mathrm{w} / \mathrm{v})$ for growth } \\
\hline Range & $0-22$ & $0-25$ & $0-25$ & $0-25$ \\
\hline Optimum & 4 & $8-10$ & $8-10$ & 10 \\
\hline \multicolumn{5}{|l|}{ Degradation of } \\
\hline Esculin & - & - & + & + \\
\hline Gelatin & + & + & + & - \\
\hline Casein & + & + & + & - \\
\hline \multicolumn{5}{|l|}{ Presence of } \\
\hline Alkaline phosphatase & + & - & w & nd \\
\hline Esterase lipase & - & $\mathrm{w}$ & - & nd \\
\hline Cystine arylamidase & - & - & $\mathrm{w}$ & nd \\
\hline$\beta$-glucosidase & - & - & + & nd \\
\hline Urease & - & - & - & + \\
\hline \multicolumn{5}{|l|}{ Acid production from } \\
\hline D-fructose & + & + & + & - \\
\hline D-maltose & + & + & + & - \\
\hline L-arabinose & - & + & - & nd \\
\hline D-ribose & + & - & - & nd \\
\hline D-xylose & - & + & - & nd \\
\hline L-xylose & $-/ w$ & - & - & nd \\
\hline D-mannose & - & - & + & nd \\
\hline D-mannitol & - & + & + & nd \\
\hline Methyl- $\alpha$-D-glucopyranoside & - & - & W & nd \\
\hline Amygdalin & - & - & $\mathrm{w}$ & nd \\
\hline Arbutin & - & - & + & nd \\
\hline Esculin & - & - & + & nd \\
\hline Salicin & - & - & + & nd \\
\hline D-melibiose & - & + & - & nd \\
\hline Sucrose & - & + & + & - \\
\hline D-melezitose & - & + & + & nd \\
\hline D-raffinose & - & + & - & nd \\
\hline Starch & - & $+\left(-^{c}\right)$ & - & nd \\
\hline Xylitol & - & - & w & nd \\
\hline Gentiobiose & - & - & + & nd \\
\hline D-turanose & - & + & + & nd \\
\hline D-tagatose & - & - & + & nd \\
\hline L-fucose & - & - & $\mathrm{w}$ & nd \\
\hline D-arabitol & - & - & + & nd \\
\hline Gluconate & - & + & + & nd \\
\hline $\mathrm{G}+\mathrm{C}$ content $(\mathrm{mol} \%)$ & $46.2 / 46.0$ & $50.1\left(51.2^{\mathrm{c}}\right)$ & 46.4 & 49.6 \\
\hline
\end{tabular}

All strains were catalase and oxidase positive. None of the strains hydrolyzed starch. Strains RH1 ${ }^{\mathrm{T}}, \mathrm{RH} 4, \mathrm{~S}$. roseus $^{\mathrm{T}}$ and $S$. hispanicus $^{\mathrm{T}}$ hydrolyzed arbutin, hippurate and hide powder azure. None of these strains hydrolyzed xylan, elastin and fibrin. Strains RH1 ${ }^{\mathrm{T}}, \mathrm{RH} 4, \mathrm{~S}$. roseus $^{\mathrm{T}}$ and $S$. hispanicus ${ }^{\mathrm{T}}$ were positive to DNAse, esterase $(\mathrm{C} 4)$, leucine arylamidase, $\alpha$-chymotrypsin, naphthol-AS-BI-phosphohydrolase and $\alpha$-glucosidase. Lipase (C14), valine arylamidase, trypsine, acid phosphatase, $\alpha$-galactosidase, $\beta$-galactosidase, $\beta$-glucuronidase, $N$-acetyl- $\beta$-glucosaminidase, $\alpha$-mannosidase, $\alpha$-fucosidase were negative. Methyl red, Voges-Proskauer and indol formation tests were negative for all strains. All organisms produced acid from D-glucose. Strains RH1 ${ }^{\mathrm{T}}$, RH4, S. roseus ${ }^{\mathrm{T}}$ and S. hispanicus ${ }^{\mathrm{T}}$ produced acid from glycerol, $N$-acetylglucosamine, D-trehalose, 2-ketogluconate and 5-ketogluconate. None of these strains produced acid from erythritol, D-arabinose, D-adonitol, methyl- $\beta$-D-xylopyranoside, D-galactose, L-sorbose, L-rhamnose, dulcitol, inositol, D-sorbitol, methyl- $\alpha$-Dmannopyranoside, D-cellobiose, inulin, glycogen, D-lyxose, D-fucose and L-arabitol- negative, + positive, $w$ weakly positive, $n d$ not determined

${ }^{\mathrm{a}}$ Our results

${ }^{\mathrm{b}}$ Results from Zhang et al. (2002)

${ }^{\mathrm{c}}$ Adapted from Ventosa et al. (1990)

Catalase, oxidase and DNAse were detected, but amylase and xylanase were not. Arbutine, hippurate, gelatine, casein and hide powder azure were hydrolyzed. These organisms did not hydrolyze elastin, fibrin and esculin. Assimilation of single carbon sources was inconclusive, as we were unable to obtain growth using any of the carbon sources examined on any of the media tested. However, formation of acid on the API $50 \mathrm{CH}$ 
test strips showed differences between the new organisms and the type strains of $S$. roseus and $S$. hispanicus (Table 1).

\section{Chemotaxonomic characteristics}

Menaquinone 6 was the major respiratory quinone. The major fatty acids of strains $\mathrm{RH} 1^{\mathrm{T}}$ and $\mathrm{RH} 4$ were $15: 0$ anteiso $(36 \%)$ and 15:0 iso (25\%). The levels of other fatty acids distinguished the type strains of the species of the genus Salinicoccus from each other (Table 2). The major amino acid constituents of the cell wall composition were glycine and lysine, which is in accordance with type A3alpha L-Lys-Gly ${ }_{5-6}$ peptidoglycan described for the genus Salinicoccus (Ventosa et al. 1990).

16S rRNA gene sequence comparison and guanine plus cytosine $(\mathrm{G}+\mathrm{C})$ content of DNA

The $\mathrm{G}+\mathrm{C}$ contents of the DNA of strains $\mathrm{RH}^{\mathrm{T}}$ and RH4 were 46.2 and $46.0 \mathrm{~mol} \%$, respectively. These values were about $4-5 \mathrm{~mol} \%$ lower than those of the type strain of $S$. roseus (Table 1). The $\mathrm{G}+\mathrm{C}$ content of the DNA of $S$. roseus was reported as $51.2 \%$ (Ventosa et al. 1990); however, our results gave a value of 50.1 (Table 1). Almost complete 16S rRNA gene sequences comprising 1,505 nucleotide positions were determined for strains $\mathrm{RH}_{1}^{\mathrm{T}}$ and $\mathrm{RH} 4$, which had identical sequences. Pairwise comparison of the 16S rRNA gene sequences showed them to be identical over the 1,505 nucleotide positions determined. Phylogenetic analyses found strains $\mathrm{RH}^{\mathrm{T}}$ and $\mathrm{RH} 4$ to group within the radiation of the species of the low $\mathrm{G}+\mathrm{C}$ Gram-positive genus Salinicoccus (Fig. 1). The lineage representing strains $\mathrm{RH} 1^{\mathrm{T}}$ and $\mathrm{RH} 4$ was distinct from those of the previously described species $S$. alkaliphilus, $S$. hispanicus and $S$. roseus and even though the similarity values are as high as $97 \%$ the low bootstrap values indicated no specific relationship of the new organisms to any of these three species. Pairwise 16S rRNA gene sequence comparisons showed the sequence of $\mathrm{RH}^{\mathrm{T}}$ to share 95.5, 96.2 and $97.0 \%$ similarity to the $16 \mathrm{~S}$ rRNA gene sequences of $S$. alkaliphilus, $S$. hispanicus and $S$. roseus, respectively.

\section{Discussion}

The phylogenetic analysis based on the 16S rRNA gene sequence of strains $\mathrm{RH}^{\mathrm{T}}$ and $\mathrm{RH} 4$ showed them to have identical sequences over the 1,505 nucleotide positions determined and to cluster with the species of the genus Salinicoccus. Strains $\mathrm{RH} 1^{\mathrm{T}}$ and $\mathrm{RH} 4$ show 16S rRNA gene sequence similarities in the range 95.5$97.0 \%$ to the previously described species of the genus Salinicoccus indicating that the new strains constitute a new species of the same genus.

The new species of the genus Salinicoccus represented by strains $\mathrm{RH} 1^{\mathrm{T}}$ and RH4 shares many of the physiological and biochemical characteristics of $S$. roseus and $S$. hispanicus, which clearly indicates that these organisms are closely related to each other and form a homogeneous group of organisms. The type strains of $S$. roseus and $S$. hispanicus were initially reported not to grow in media without $\mathrm{NaCl}$, in contrast to $S$. alkaliphilus, which grew in media without additional $\mathrm{NaCl}$ (Zhang et al. 2002). We found that strains $\mathrm{RH} 1^{\mathrm{T}}$, RH4 as well as the type strains of $S$. roseus and $S$. hispanicus grew in $\mathrm{MH} 10 \%$ medium without additional $\mathrm{NaCl}$; this medium contained only $0.90 \mathrm{mM} \mathrm{Na}{ }^{+}$, however, the growth rate was much lower than in medium containing 4 or $8 \% \mathrm{NaCl}$.

Strains $\mathrm{RH}^{\mathrm{T}}$ and $\mathrm{RH} 4$ can be distinguished from the type strains of the species previously described of the
Table 2 Mean fatty acid composition of strains $\mathrm{RH}^{\mathrm{T}}{ }^{\text {, }}$ RH4 and type strains of Salinicoccus roseus, Salinicoccus hispanicus and Salinicoccus alkaliphilus

\footnotetext{
- not detected

${ }^{a}$ Values for fatty acids present at levels of less than $0.5 \%$ are not shown

${ }^{\mathrm{b}}$ Results from Zhang et al. (2002)

${ }^{\mathrm{c}}$ Unknown fatty acid with an equivalent chain length 15.670

${ }^{\mathrm{d}}$ Group of fatty acids $(17: 1$ iso I and/or 17:1 anteiso B) that could not be separated by this method
}

\begin{tabular}{|c|c|c|c|c|}
\hline Fatty acid ${ }^{\mathrm{a}}$ & $\mathrm{RH}^{\mathrm{T}} / \mathrm{RH} 4$ & S. roseus $^{\mathrm{T}}$ & S. hispanicus ${ }^{\mathrm{T}}$ & S. alkaliphilus ${ }^{\mathrm{Tb}}$ \\
\hline $14: 0$ iso & $1.0 \pm 0.1$ & $2.1 \pm 0.3$ & $5.8 \pm 1.3$ & 4.4 \\
\hline 14:0 & $0.8 \pm 0.2$ & $1.2 \pm 0.3$ & $5.3 \pm 0.4$ & 1.6 \\
\hline $15: 0$ iso & $26.6 \pm 2.2$ & $21.4 \pm 1.2$ & $25.9 \pm 3.4$ & 22.3 \\
\hline 15:0 anteiso & $35.3 \pm 0.7$ & $36.0 \pm 2.3$ & $15.6 \pm 3.6$ & 27.6 \\
\hline $15: 0$ & - & $2.1 \pm 0.6$ & $5.4 \pm 0.8$ & - \\
\hline 16:1 $\omega 7 c$ alcohol & - & $0.8 \pm 0.3$ & $1.6 \pm 0.1$ & 5.8 \\
\hline $16: 0$ iso & $3.5 \pm 0.6$ & $5.3 \pm 0.8$ & $5.5 \pm 1.0$ & 10.1 \\
\hline Unknown $^{c}$ & $2.3 \pm 0.3$ & $2.0 \pm 0.4$ & $8.2 \pm 2.3$ & 0.9 \\
\hline $16: 1 \omega 11 c$ & - & - & $2.0 \pm 0.2$ & 2.2 \\
\hline $16: 0$ & $2.9 \pm 0.4$ & $3.0 \pm 0.7$ & $10.3 \pm 2.3$ & 1.1 \\
\hline $17: 1 \omega 10 c$ iso & $3 \pm 0.3$ & $1.5 \pm 0.4$ & $0.7 \pm 0.1$ & 4.0 \\
\hline Sum in feature $5^{\mathrm{d}}$ & $0.7 \pm 0.1$ & $0.5 \pm 0.1$ & - & - \\
\hline $17: 0$ iso & $9.5 \pm 0.8$ & $5.6 \pm 0.3$ & $4.6 \pm 0.9$ & 3.3 \\
\hline 17:0 anteiso & $8.5 \pm 0.6$ & $8.0 \pm 1.0$ & $1.6 \pm 0.7$ & 8.9 \\
\hline $17: 0$ & - & $0.5 \pm 0.2$ & $0.9 \pm 0.3$ & - \\
\hline 18:0 & $0.7 \pm 0.1$ & $1.1 \pm 0.2$ & $2.4 \pm 0.8$ & - \\
\hline $19: 0$ iso & $3.0 \pm 0.1$ & $4.0 \pm 0.3$ & $1.1 \pm 0.3$ & 2.8 \\
\hline 19:0 anteiso & $1.0 \pm 0.2$ & $2.3 \pm 0.5$ & - & 1.9 \\
\hline $19: 0$ & - & $1.0 \pm 0.3$ & $0.6 \pm 0.1$ & - \\
\hline $20: 0$ iso & - & $0.6 \pm 0.1$ & - & 1.5 \\
\hline 20:0 & $2.1 \pm 0.5$ & $1.5 \pm 0.4$ & $2.2 \pm 0.2$ & 1.3 \\
\hline
\end{tabular}


Fig. 1 16S rRNA gene sequence based phylogeny showing the relationships of strain $\mathrm{RH} 1^{\mathrm{T}}$ and related taxa. The dendrogram was constructed from distance matrices using the neighbourjoining method. Numbers at branching points represent bootstrap values from 1,000 replicates. Scale bar, one inferred nucleotide substitution per 100 nucleotides

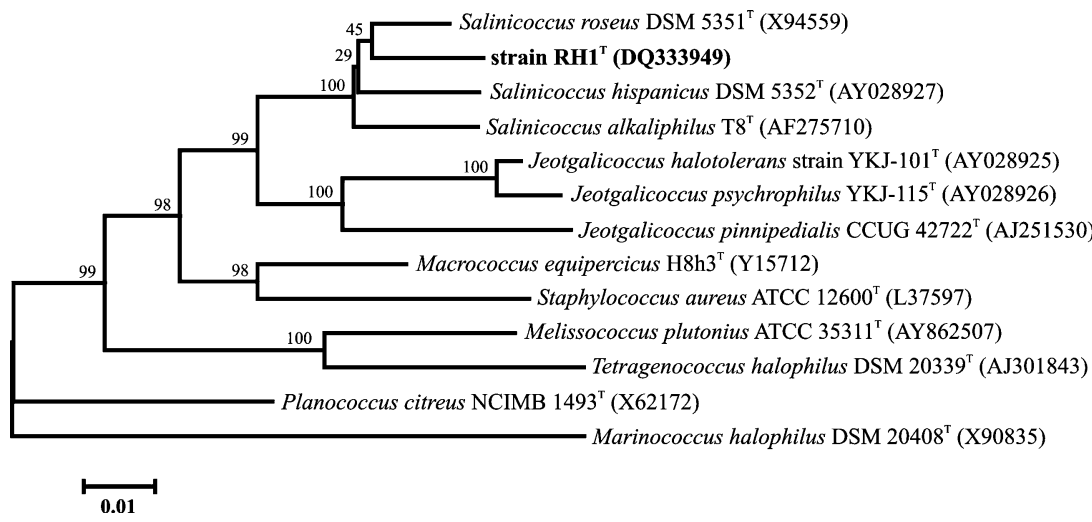

genus Salinicoccus by the lower optimum $\mathrm{NaCl}$ concentration for growth, by acid production from different carbohydrates and by differences in fatty acid composition. The higher $\mathrm{pH}$ range of $S$. alkaliphilus also serves to distinguish this species from the other species of the genus, which includes the new organisms isolated from salted skate.

On the basis of the results presented in this study, we are of the opinion that strains $\mathrm{RH} 1^{\mathrm{T}}$ and $\mathrm{RH} 4$ represent a new species of the genus Salinicoccus for which we propose the name $S$. salsiraiae.

\section{Description of Salinicoccus salsiraiae}

Salinicoccus salsiraiae (sal.si.ra'i.a.e. L. adj. salsus, salted; L. n. raia, a ray; N.L. gen. n. salsiraiae, of a salted ray). S. salsiraiae forms spherical cells, Gram-positive, $1.0-2.5 \mu \mathrm{m}$ in diameter, occurring singly, in pairs, tetrads or clumps. The cells are not motile and non-spore forming. Strain $\mathrm{RH}^{\mathrm{T}}$ forms pink-red colonies and flocculates in liquid media. The optimal salt concentration for growth is $4 \%(\mathrm{w} / \mathrm{v})$, growth occurs in medium without additional salt and in medium containing $22 \%$ $\mathrm{NaCl}$. Growth occurs at 20 and $45^{\circ} \mathrm{C}$; the optimum growth temperature for strain $\mathrm{RH} 1^{\mathrm{T}}$ is about $37^{\circ} \mathrm{C}$. The optimum $\mathrm{pH}$ is about 8.0; growth occurs between $\mathrm{pH} 6.5$ and 9.5. The major fatty acids are 15:0 iso and 15:0 anteiso. Menaquinone 6 is the major respiratory quinone. The peptidoglycan is of the A3alpha L-Lys-Gly 5-6 type. Strain $\mathrm{RH}^{\mathrm{T}}$ is strictly aerobic and reduces nitrate to nitrite. Cytochrome oxidase, catalase and DNAse are produced; arbutin, hippurate, gelatine, casein and hide powder azure are degraded. This organism produces acid from D-ribose, glycerol, D-glucose, D-fructose, $\mathrm{N}$ acetylglucosamine, D-maltose, D-trehalose, 2-ketogluconate and 5-ketogluconate.

The DNA of strain $\mathrm{RH}^{\mathrm{T}}$ has a $\mathrm{G}+\mathrm{C}$ content of $46.2 \mathrm{~mol} \%$. This bacterium was isolated from a salted ray (skate). Strain $\mathrm{RH} 1^{\mathrm{T}}$ has been deposited in the Universiteit Gent, Laboratorium voor Microbiologie, Gent, Belgium as strain LMG 22840 and the Collection de l'Institut Pasteur, Paris, France as strain CIP 108576.
Acknowledgments We are indebted to Prof. J. Euzéby (École National Vétérinaire, Toulouse, France) for the etymology of the new organism's name. We thank Dr Peter Schumann (DSMZ, Germany) for the peptidoglycan analysis.

\section{References}

Degryse E, Glansdorff N, Pierard A (1978) A comparative analysis of extreme thermophilic bacteria belonging to the genus Thermus. Arch Microbiol 117:189-196

Felsenstein J (1993) PHYLIP (phylogenetic inference package), version 3.5.1. Department of Genetics, University of Washington, Seattle

Freitas M, Rainey FA, Nobre MF, Silvestre AJD, da Costa MS (2003) Tepidimonas aquatica sp. nov., a new slightly thermophilic $\beta$-Proteobacteria isolated from a hot water tank. Syst Appl Microbiol 26:376-381

Jukes TH, Cantor CR (1969) Evolution of protein molecules. In: Munro HN (ed) Mammalian protein metabolism. Academic, New York, pp 21-132

Maidak BL, Cole JR, Parker CT et al (1999) A new version of the RDP (Ribosomal Database Project). Nucleic Acids Res 27:171173

Marquez MC, Ventosa A, Ruiz-Berraquero F (1990) Marinococcus hispanicus, a new species of moderately halophilic Gram-positive cocci. Int J Syst Bacteriol 40:165-169

Mesbah M, Premachandran U, Whitman W (1989) Precise measurement of the $\mathrm{G}+\mathrm{C}$ content of deoxyribonucleic acid by high performance liquid chromatography. Int $\mathbf{J}$ Syst Bacteriol 39:159-167

Moreira C, Rainey FA, Nobre MF, da Silva MT, da Costa MS (2000) Tepidimonas ignava gen. nov., sp. nov., a new chemolithoheterotrophic and slightly thermophilic member of the $\beta$ Proteobacteria. Int J Syst Evol Microbiol 50:735-742

Nielsen P, Fritze D, Priest FG (1995) Phenetic diversity of alkaliphilic Bacillus strains: proposal for nine new species. Microbiology 141:1745-1761

Nunes OC, Donato MM, da Costa MS (1992) Isolation and characterization of Rhodothermus strains from S. Miguel, Azores. Syst Appl Microbiol 15:92-97

Rainey FA, Ward-Rainey N, Kroppenstedt RM, Stackebrandt E (1996) The genus Nocardiopsis represents a phylogenetically coherent taxon and a distinct actinomycete lineage: proposal of Nocardiopsaceae fam. nov. Int J Syst Bacteriol 46:10881092

Santos MA, Williams RAD, da Costa MS (1989) Numerical taxonomy of Thermus isolates from hot springs in Portugal. Syst Appl Microbiol 12:310-315

Schleifer KH (1985) Analysis of the chemical composition and primary structure of murein. Methods Microbiol 18:123156 
Schleifer KH, Kandler O (1972) Peptidoglycan types of bacterial cell walls and their taxonomic implications. Bacteriol Rev 36:407-477

Tiago I, Chung AP, Veríssimo A (2004) Bacterial diversity in a nonsaline alkaline environment: heterotrophic aerobic populations. Appl Environ Microbiol 70:7378-7387

Tindall BJ (1989) Fully saturated menaquinones in the archaebacterium Pyrobaculum islandicum. FEMS Microbiol Lett 60:251-254

Ventosa A, Quesada E, Rodriguez-Valera F, Ruiz-Berraquero F, Ramos-Cormenzana A (1982) Numerical taxonomy of moderately halophilic Gram-negative Rods. J Gen Microbiol 128:1959-1968
Ventosa A, Marquez MC, Ruiz-Berraquero F, Kocur M (1990) Salinicoccus roseus gen. nov., a new moderately halophilic Gram-positive coccus. Syst Appl Microbiol 13:29-33

Ventosa A, Marquez MC, Weiss N, Tindall BJ (1992) Transfer of Marinococcus hispanicus to the genus Salinicoccus as $\mathrm{Sa}$ linicoccus hispanicus comb. nov. Syst Appl Microbiol 15:530 534

Zhang W, Xue Y, Ma Y, Zhou P, Ventosa A, Grant WD (2002) Salinicoccus alkaliphilus sp. nov., a novel alkaliphile and moderate halophile from Baer soda lake in inner Mongolia Autonomous Region, China. Int J Syst Evol Microbiol 52:789793 